\title{
CT myelography characteristics of spinal dysraphism in a young mixed breed dog
}

\author{
Características de mielografía con TC de una disrafia espinal en un \\ perro mestizo joven \\ M Gómez ${ }^{\mathrm{a}}$, M Mieres ${ }^{\mathrm{b}}, \mathrm{JC}_{\text {Gutiérrez }}^{\mathrm{a}}, \mathrm{JC}_{\text {Jones }}{ }^{\mathrm{c}, \mathrm{d}}$ \\ anstituto de Farmacología y Morfofisiología, Facultad de Ciencias Veterinarias, Universidad Austral de Chile, Valdivia, Chile. \\ bInstituto de Ciencias Clínicas Veterinarias, Facultad de Ciencias Veterinarias, Universidad Austral de Chile, Valdivia, Chile. \\ ${ }^{\mathrm{c}}$ Division of Animal and Nutritional Sciences, West Virginia University, Morgantown, West Virginia, USA. \\ ${ }^{\mathrm{d}}$ West Virginia University Agricultural and Forestry Experiment Station Scientific, West Virginia, USA.
}

\section{RESUMEN}

\begin{abstract}
La disrafia espinal es un defecto congénito de la columna vertebral y la médula espinal secundaria a un cierre imperfecto del neuroporo caudal del tubo neural en desarrollo. Este reporte describe las características observadas en una mielografía por tomografía computarizada (mielo-TC) de una espina bífida oculta, aplasia/hipoplasia segmentaria de médula espinal y duplicación de médula espinal tipo II (diplomielia) en el segmento lumbar caudal de un perro mestizo de dos meses de edad.

Key words: dysraphism, split cord malformation, dog.

Palabras clave: disrafismo, duplicación de médula espinal, perro.
\end{abstract}

\section{INTRODUCTION}

Spinal dysraphism is a developmental disorder that is characterized by several structural and functional abnormalities of the spinal cord, vertebral column, muscles and skin (McGeady et al 2006). This congenital defect results from the failure of the neural tube closure with imperfect fusion of midline mesenchymal, neuroecotermal and cutaneous ectodermal components (Hoskins 2001). Failure of neural tube closure may arise from faulty induction of the underlying notochord or from other genetic, teratogenic, metabolic and nutritional factors (Hrubec et al 2006, McGeady et al 2006). Lesions observed with spinal dysraphism include spina bifida (defective fusion of the vertebral arch), hemivertebrae, fused vertebrae, vertebral canal stenosis, meningocele (protrusion of meninges through the defect), myelocele (protrusion of spinal cord through the defect) and meningomyelocele (protrusion of both meninges and spinal cord) (McGeady et al 2006, De Lahunta and Glass 2009). Pathological changes may also include spinal cord lesions such as myeloschisis (spinal cord cleft), amyelia, diastematomyelia (split cord malformation type I), diplomyelia (split cord malformation type II), absent or misshapen dorsal and ventral horns, hydromyelia

Accepted: 12.12.2011.

* Casilla 567, Valdivia, Chile; marcelogomez@uach.cl and syringomyelia (Andro et al 2009). Most lesions occur in the caudal lumbar, sacral and coccygeal regions of the vertebral column (Hoskins 2001). Spinal dysraphism has been documented in Weimaraner, Rottweiller, Alaskan Malamute, Chuihuahua, Collie, Golden Retreiver, Dalmatian, West Highland White Terrier, English Bulldog, Samoyed, Mongrel, Dalmatian, Irish Setter, Pekingese and mixed breeds (Clayton and Boyd 1983, Braund 1994, Mattos Junior et al 2004, Mônica et al 2008). In Weimaraners spinal dysraphism is transmitted by a co-dominant lethal gene with a reduced penetrance and variable expressivity (Shelton 1977, De Lahunta and Glass 2009).

This report describes computed tomographic myelography characteristics of spina bifida occulta, spinal cord aplasia/hypoplasia and split cord malformation type II in the caudal lumbar area of a 2 month old mixed breed dog.

\section{MATERIAL AND METHODS}

A 2 month old female mixed breed dog weighing $2.5 \mathrm{~kg}$ was evaluated at the Veterinary Hospital of Austral University of Chile because of a history of non-progressive altered gait, and fecal incontinence since the present owner had the dog (around 4 weeks of age). Physical examination revealed scars in the perineal area, a short tail and a palpable depression in the spinous process of the sixth lumbar vertebra. Neurological examination demonstrated mild ambulatory paraparesis, symmetric pelvic limb ataxia, proprioceptive deficits in both pelvic limbs, decreased 
patellar reflexes in both pelvic limbs, bunny-hopping gait (symmetric bilateral protraction of pelvic limbs), mild atrophy of the pelvic limb musculature, and hypoaesteshia in the perineal region and pelvic limbs. Neurological findings indicated a LMN signs for the sciatic and pudendal nerve distribution and were consistent with a lesion at the lumbosacral (L4-Cd5) spinal cord segments. Diagnostic imaging test included radiography, ultrasonography and computed tomographic myelography (Myelo-CT). Radiography revealed absence of the lamina and spinous process of the $6^{\text {th }}$ lumbar vertebra. Ultrasonographic evaluation at the lumbar area showed absence of spinous processes at L6 vertebral level. Examination at this area in transverse and sagittal planes showed a round hyperechoic dura mater, and a hypoechoic space corresponding to the subarachnoid space. However, no spinal cord anomalies were detected on the sonographic images. The dog was placed under general anesthesia and Myelo-CT was performed using a four generation CT scanner (Picker
4000 Medical System, Ohio, USA). Immediately prior to CT scanning, and injection of $0.3 \mathrm{cc} / \mathrm{kg}$ of iodinated contrast medium (Iohexol, Omnipaque $®$ ) was made into the subarachnoid space at the level of the atlanto-occipital junction. Computed tomographic myelography images revealed incomplete vertebral arches in L6 consistent with spina bifida, and a small meningocele sac at L6. At the L5-L6 and cranial L6 vertebral levels a division of the spinal cord was observed consistent with a segmental type II split cord malformation (diplomyelia). Both hemicords were located in a single dural cavity and the space between the hemicords was filled with a contrast material (figure 1). Caudally, absence of the spinal cord at the L6 vertebral level and reduced diameter of the spinal cord were evident with an increased size of the subarachnoid space at L7. These characteristics were consistent with segmental spinal cord aplasia and hypoplasia respectively (figure 2). After medical recommendation, the owner declined the use of surgical intervention since neurological signs were
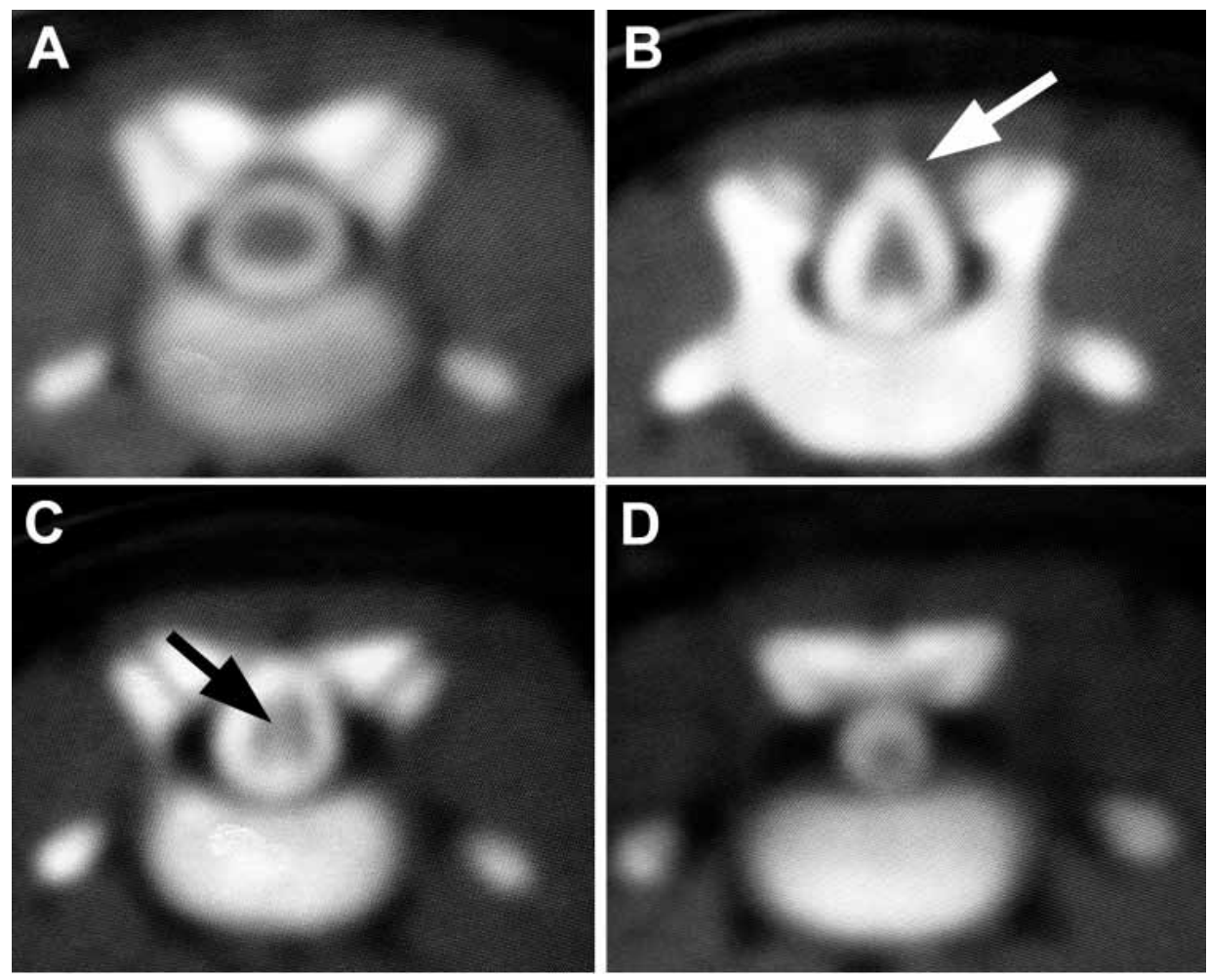

Figure 1. Myelo-CT findings of spinal dysraphism abnormalities in a two month old mixed breed dog. A: normal dural sac at L2/L3 vertebral segment. B: Absence of vertebral arch, abnormal triangular shape of the spinal cord and mild meningocoele (white arrow) at cranial L6 vertebral segment C: diplomyelia (split cord malformation type II), at caudal L6 vertebral segment. A fine radiopaque line of contrast medium is observed between the two hemicords (black arrow). D: hipoplasia of the spinal cord at L7.

Hallazgos de mielo-TAC de un disrafismo espinal en un perro mestizo de dos meses de edad. A: saco dural normal en el segmento vertebral L2/L3. B: Ausencia de arco vertebral, forma triangular anormal de la médula espinal y meningocele leve (flecha blanca) a nivel craneal del segmento vertebral L6. C: diplomielia (duplicación espinal tipo II). Se observa una fina línea radiopaca de medio de contraste entre dos hemimédulas espinales (flecha negra) a nivel caudal del segmento vertebral L6. D: hipoplasia de médula espinal a nivel de segmento vertebral L7. 


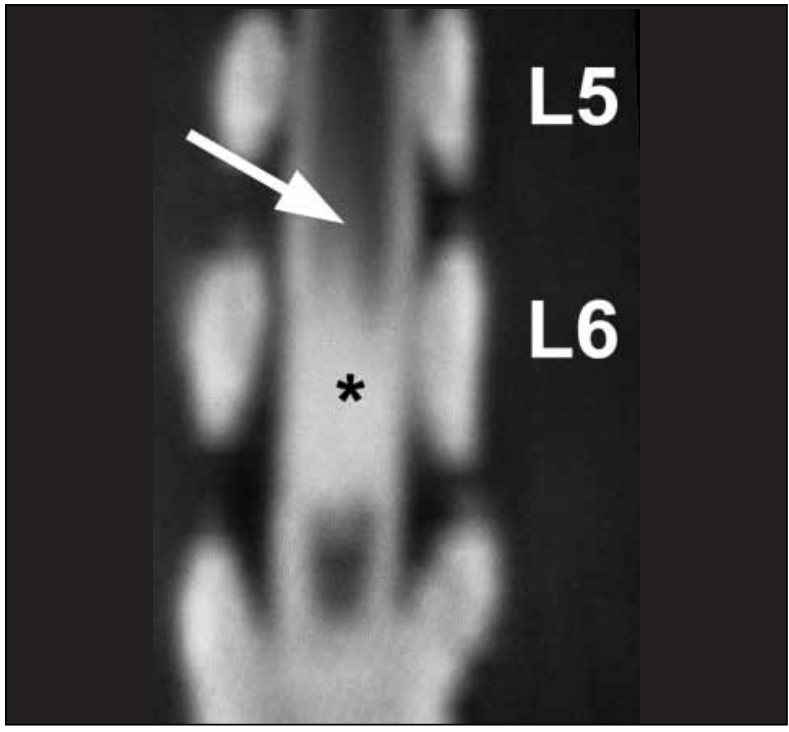

Figure 2. Computed tomographic myelography image of the caudal lumbar spine in a two month old dog with spinal dysraphism, displayed using dorsal planar reformatting. Notice the area of diplomyelia (white arrow) at L5/L6 and segmental spinal cord aplasia at L6 (*).

Imagen de una mielografía por tomografía computarizada, utilizando reformateado dorso-planar, de la columna lumbar caudal en un perro mestizo de dos meses de edad con disrafia espinal. Nótese el área de diplomielia (flecha blanca) a nivel de L5/L6 y la aplasia segmentaria de médula espinal a nivel de L6 $(*)$.

consider mild and stable. Follow up telephonic conversations over the next 3 months revealed that the owner did not notice additional neurologic signs in the dog. There was no additional information available from the mother related to drugs that may have taken during her pregnancy or exposure to infectious agents or chemicals.

\section{RESULTS AND DISCUSSION}

Notochordal neural tube and dysraphic anomalies are congenital defects associated to imperfect closure of the cranial neuropore, the neural tube and the caudal neuropore (McGeady 2006). Dysraphism conditions can occur in the cranium (anencephalia, exencefalia, cranium bifidum, encephalocele, meningocele) or in the spinal cord. Spinal dysraphism includes dorsal midline defects derived from the secondary mal-development of ectoderm, mesoderm, and neurectoderm layers of tissue, and encompasses a variety of malformations including spina bifida, meningocele, meningomyelocele, syringomyelia, split cord anomalies (diplomyelia, diastematomyelia), and others (De Lahunta and Glass 2009). Environmental, genetic, and nutritional factors have been reported to cause neural tube defects in laboratory mice including drugs, physical agents (hyperthermia), vitamin excess or deficiency (folic acid), maternal infectious and metabolic diseases (Gutierrez et al 2006, Hrubec et al 2006). Among the metabolic diseases, maternal diabetes produces $6-10 \%$ or three to five times more malformations in human pregnancies complicated by hyperglycemia, compared to non-diabetic pregnancies including neural tube defects (NTDs) in the form of excencephaly and spina bifida (Gutierrez et al 2006).

In the present case, Myelo-CT demonstrated severe soft tissue abnormalities that were not evident from radiography and ultrasonography. These included duplication of the spinal cord with one dural sac (diplomyelia), segmental aplasia and hypoplasia of the spinal cord. Pang et al (1992) classified split spinal cord malformation as type I or diastematomyelia where two individual dural tubes are found, sometimes separated by an osseous or cartilaginous septum. Split cord malformation type II or diplomyelia consists of two hemicords housed within a single dural sac separated by a fibrous septum (Pang et al 1992). Previous human studies have also demonstrated that the severity of spinal dysraphism lesion may be underestimated with radiography and ultrasonography, and have recommended that patients should also be evaluated using MRI or Myelo-CT to delineate spinal cord lesions, the position of neural structures and associated anomalies (Orakdogen et al 2009). Imaging techniques can also aid in the planning of surgical interventions (Bailey and Morgan 1992). Ultrasound evaluation has been useful in detecting split cord malformations in human fetuses and infants and also young animals (Dick et al 2001, Testoni et al 2010). However, the sonographic evaluation on this case was unable to provide additional information about the spinal cord anomaly probably due to advance stage of vertebral ossification in the dog. Computed tomographic myelography findings in the dog of this report were consistent with type II split cord malformation. These spinal cord lesions most likely occurred during primary neurulation and are uncommon in domestic animals. Spinal cord duplications are often associated with vertebral anomalies such as spina bifida, as seen in this case. Computed tomography without contrast can be used to demonstrate bone lesions defects and malformations (Thrall 2007). In humans, method of choice for evaluation of vertebral anomalies is high resolution CT scan with bone window and thin or utltrathin section in the area of interest (Schijman 2003). Additionally, three-dimensional CT reformatting software tools can be used to more clearly visualize the surface appearance of the vertebral column defects including spina bifida, hemivertebrae and others. Computed tomographic myelography can also detect variations in the shape, size and split defects of spinal cord and in this case it was helpful in determining the location and extent of the spinal dysraphism, the spinal cord malformation type II and spinal cord hypoplasia. Magnetic resonance imaging has been described as the preferred imaging modality for assessment of spinal dysraphism, meningoceles, myelomeningoceles in small animals (Da Costa 2010). This is the first report assessing spinal cord duplication in dogs using CT myelography. 
Clinical signs in this case were consistent with a lumbosacral (L3-Cd4) spinal cord lesion. The neurologic localization was supported by the Myelo-CT findings. Spinal cord myelodysplastic lesions are frequently found on thoracic, lumbar, sacral and caudal segments and lower motor signs in the distribution of the sciatic, pudendal and caudal nerves are predominant (Hoskins 2001). Mild paraparesis, bunny hopping, decreased flexor reflexes in pelvic limbs and decreased perineal reflex and urinary-fecal incontinence are common neurologic findings (Hoskins 2001, Dewey 2003). Usually these neurologic signs are nonprogressive and present from birth (Dewey 2003). The cause of these clinical signs is believed to be a microscopic alteration in the ventral commissural interneurons in the lumbosacral intumescence that are involved with gait (De Lahunta and Glass 2009). The dimpling of the skin and abnormal pattern of the haircoat over L6 in the dog of this report is also consistent with previous reports (Mattos et al 2007). Scar at the perineal area were probably due to previous decubitus ulcers or skin irritation associated to decrease sensation at the perineal area.

In utero surgical repair of spina bifida has been successful in preventing or minimizing neurologic deficits in humans and sheep (Meuli et al 1995, Sutton 2008). Prevention of NTDs in humans has been reported from maternal periconceptional supplementation with folic acid, although the protective mechanism remains unclear (Blencowe et al 2010). Humans patients who are ambulatory with non-progressive signs may have an acceptable adult life. Because of the mild neurologic dysfunction, owners of the dog from this report declined surgery and chose to keep the dog as pet.

\section{SUMMARY}

Spinal dysraphism is a congenital defect of the vertebral column and spinal cord secondary to imperfect closure of the caudal neuropore of the developing neural tube. This report describes computed tomographic myelography (Myelo-CT) characteristics of spina bifida occulta, spinal cord aplasia/hypoplasia and split cord malformation type II (diplomyelia) in the caudal lumbar area of a 2 month old mixed breed dog.

\section{REFERENCES}

Andro C, R Pecquery, P De Vries, P Forlodou, B Fenoll. 2009. Split cervical spinal cord malformation and vertebral dysgenesis. Orthop Traumatol Surg Res 95, 547-550.

Bailey CS, JP Morgan. 1992. Congenital spinal malformations. Vet Clin North Am Small Anim Pract 22, 985-1015.
Blencowe H, S Cousens, B Modell, J Lawn. 2010. Folic acid to reduce neonatal mortality from neural tube disorders. Int J Epidemiol 1, 110-121.

Braund KG. 1994. Clinical syndromes in veterinary neurology. $2^{\text {nd }} \mathrm{ed}$. Mosby Publishers, St Louis, USA, Pp 257-258.

Clayton HM, JS Boyd. 1983. Spina bifida in a German shepherd puppy. Vet Rec 112, 13-15.

Da Costa RC, SA Moore. 2010. Advanced imaging of the spine in small animals. Vet Clin North Am Small Anim Pract 40, 755-763.

De Lahunta A, E Glass. 2009. Veterinary Neuroanatomy and Clinical Neurology. $2^{\text {nd }}$ ed. Saunders, Philadelphia, USA.

Dewey CW. 2003. Canine and feline neurology. Iowa State Press, Ames, USA.

Dick EA, K Patel, CM Owens, R de Bruyn. 2002. Spinal ultrasound in infants. Br J Radiol 75, 384-392.

Gutierrez JC, TC Hrubec, MR Prater, BJ Smith, LE Freeman, SD Holladay. 2007. Aortic and ventricular dilation and myocardial reduction in gestation day 17 ICR mouse fetuses of diabetic mothers. Birth Defects Res A Clin Mol Teratol 79, 459-464.

Hoskins J. 2001. Veterinary pediatrics: dogs and cats from birth to six months. $3^{\text {rd }}$ ed. Saunders, Philadelphia, USA.

Hrubec TC, M Yan, K Ye, CM Salafia, SD Holladay. 2006. Valproic acid-induced fetal malformations are reduced by maternal immune stimulation with granulocyte-macrophage colony-stimulating factor or interferon-gamma. Anat Rec A Discov Mol Cell Evol Biol 288, 1303-1309.

McGeady TA, PJ Quinn, ES FitzPatrick, MT Ryan. 2006. Veterinary Embriology. Blackwell Publishing, Oxford, UK.

Mattos Junior E, E Alcântara Ribeiro, J von Glehn dos Santos, C Russo, S Arlington Headley. 2007. Spina bifida in a dead stillbirth mongrel dog. Semina: Ciências Agrárias, Londrina 28, 295-298.

Meuli M, C Meuli-Simmen, GM Hutchins, CD Yingling, KM Hoffman, MR Harrison, NS Adzick. 1995. In utero surgery rescues neurological function at birth in sheep with spina bifida. Nat Med 1, 342-347.

Mônica V B, M Arias, A Rogério, F Marcasso, S Margalho, Sierra, M de Oliveira, R. Oliveira. 2008. Spina bifida in three dogs. Braz J Vet Pathol 1, 64-69.

Orakdogen M, C Turk, M Ersahin, N Biber, Z Berkman. 2009. Spinal Disrafizm Olgular. Spinal Dysraphisms of the Cervicothoracic Region in Childhood. Turkish Neurosurgery 19, 400-405.

Pang D, MS Dias, M Ahab-Barmada. 1992. Split cord malformation: Part I: a unified theory of embryologenesis for double spinal cord malformations. Neurosurgery 31, 451-480.

Schijman E. 2003. Split spinal cord malformations: Report of 22 cases and review of the literature. Childs Nerv Syst 19, 96-103.

Shamir M, S Rochkind, D Johnston. 2001. Surgical treatment of tethered spinal cord syndrome in a dog with myelomeningocele. Vet $\operatorname{Rec} 148,755-756$.

Shelton MC. 1977. A possible mode of inheritance for spinal dysraphism in the dog with a more complete description of the clinical syndrome. Magister Theses. Iowa State University, Ames, USA.

Sutton LN. 2008. Fetal surgery for neural tube defects. Best Pract Res Clin Obstet Gynaecol 22, 175-188.

Testoni S, Grandis A, Diana A, Dalla Pria A, Cipone M, Bevilacqua D, Gentile A. 2010. Imaging diagnosis-ultrasonographic diagnosis of diplomyelia in a calf. Vet Radiol Ultrasound 51, 667-669.

Thrall D. 2007. Textbook of veterinary radiology. $5^{\text {th }}$ ed. Saunders, St Louis, Missouri, USA. 